\title{
Effect of Cilostazol in \\ Alleviating Cardiovascular Complications through Regulation of Type 1 \\ Plasminogen Activator Inhibitor and Transforming Growth Factor- $\beta_{1}$ Overexpression in Experimental Rats
}

\author{
Rasha Hussieny MOHAMED
}

\begin{abstract}
Department of Biochemistry, Faculty of Pharmacy, Zagazig University, Zip code 44511, Zagazig, Egypt. E-mail: rashahussieny@yahoo.com

Sci Pharm. 2008; 76: 699-711

doi:10.3797/scipharm.0809-05

Published: $\quad$ November $14^{\text {th }} 2008$

Accepted: $\quad$ November $8^{\text {th }} 2008$

Received: $\quad$ September $14^{\text {th }} 2008$

This article is available from: http://dx.doi.org/10.3797/scipharm.0809-05

(c) Mohamed; licensee Österreichische Apotheker-Verlagsgesellschaft m. b. H., Vienna, Austria.

This is an Open Access article distributed under the terms of the Creative Commons Attribution License (http://creativecommons.org/licenses/by/3.0/), which permits unrestricted use, distribution, and reproduction in any medium, provided the original work is properly cited.
\end{abstract}

\begin{abstract}
Cilostazol is a potent phosphodiesterase inhibitor; its major effects are prevention of platelet aggregation and dilation of blood vessels via an increase in tissue cAMP levels. This study examined the effect of cilostazol on serum cAMP, type 1 plasminogen activator inhibitor and transforming growth factor- $\beta_{1}$ in relation to alleviating cardiovascular complications. This was achieved in rats through administration of L-NAME $(0.1 \mathrm{mg} / \mathrm{ml})$ for two weeks, and then followed by i.p. single dose of streptozotocin $(65 \mathrm{mg} / \mathrm{kg})$. Rats were classified to three groups; normal rats, control diabetic hypertensive rats and the third group was treated with cilostazol (1.8 mg daily, orally) for six weeks. Cilostazol improved serum cAMP level and increased plasma NO concentration leading to dilation of blood vessels. In addition, cilostazol has beneficial lipoprotein-modifying effect. Cilostazol treatment confirmed the positive correlation between plasma PAI-1 activity and serum TGF- $\beta_{1}$ which is beneficial in reducing the hazards of cardiovascular complications. Thus, cilostazol therapy provides a broad spectrum of effects in alleviating cardiovascular complications induced in experimental animals.
\end{abstract}




\section{Keywords}

Cilostazol. phosphodiesterase inhibitor • Cyclic AMP • Plasminogen activator inhibitor-1 • Transforming growth factor- $\beta_{1} \bullet$ Cardiovascular complications.

\section{Introduction}

Endothelial dysfunction plays a key regulatory role in initiation of cardiovascular complications (CVC) [1]. Epidemiologic data has confirmed an increased likelihood of developing CVC when hypertension and diabetes mellitus (DM) are combined [2]. The relationship among endothelial function, diabetes, and hypertension is complex whereas hypertensive-diabetic rats show more severe coronary microvascular abnormalities [3]. Moreover, there is an increased prevalence of hypertension in diabetic patients and vice versa, suggesting that both conditions commonly coexist [4]. Hypertension exacerbates diabetic cardiomyopathy, indeed, hypertension is well documented as an important risk factor for myocardial infarction and stroke. These complications are predominantly occurring due to thrombosis of arterioles [5].

Plasminogen activator inhibitor-1 (PAI-1) is well-established marker of endothelial dysfunction in several pathological conditions [6]. Disregulation of PAl-1 expression plays a potential role not only in thrombosis [7] but also in the formation of tissue fibrosis [8]. Nevertheless, PAI-1 is significantly elevated in diabetic patient before the onset of clinical vascular complication. Interestingly, PAI-1 is markedly upregulated by transforming growth factor- $\beta_{1}$ (TGF- $\left.\beta_{1}\right)$, which could directly increase PAI-1 mRNA levels of endothelial cells by promoting gene transcription [9]. Consequently, both PAI-1 and TGF- $\beta_{1}$ may be taken as meaningful biomarkers for incidence and propagation of cardiovascular complications.

Endothelial dysfunction in hypertensive diabetic rats involves a decreased production or bioavailability of nitric oxide (NO) [10]. Definitely, chronic NO blockade enhances thrombus formation as demonstrated by increased plasma levels of PAI-1. This NO decrement is concomitant with a decrease in arterial wall content of cyclic adenosine monophosphate (cAMP) [11]. Cyclic AMP is the second messenger which can regulate the fibroblasts in many tissues. Several studies reported that cAMP analogues, which increase intracellular cAMP concentration, inhibit platelet aggregation. Cyclic nucleotide phosphodiesterases (PDEs) are the major enzymes involved in metabolic processing of cyclic AMP and cyclic GMP $[12,13]$.

Specifically, Type III phosphodiesterase inhibitor (PDE3) is the only cyclic AMP-regulating isozyme expressed in both vascular smooth muscle cells (VSMC) and platelets, so, its inhibition has been shown to block platelet aggregation and proliferation of VSMC in vitro [14].

Cilostazol $\{6$-[4-(1-cyclohexyl-1H-tetrazol-5-yl)butoxy]-3,4-dihydroquinolin-2(1H)-one $\}$ is a specific inhibitor of PDE3. Its major effects are prevention of platelet aggregation and a dilation of blood vessels via an increase in tissue cAMP levels through blocking its hydrolysis by type III phosphodiesterase $[15,16]$. It also improved postprandial lipemia in diabetic patients [17]. 
Thereby, this study threw the light firstly, on the role of PAI- 1 and TGF- $\beta_{1}$ in the incidence of endothelial dysfunction and its propagation to cardiovascular complications; secondly, to estimate the extent of association between CAMP and both PAI-1 and TGF- $\beta_{1}$; thirdly, to evaluate the efficacy of type III phosphodiesterase inhibitor for alleviating cardiovascular complications.

\section{Materials and Methods}

\section{Experimental animals}

Male Wistar rats with an initial body weight of 200 to $230 \mathrm{~g}$ were supplied by the Egyptian Organization for Biological Products and Vaccines. Rats were subjected to controlled conditions of temperature $\left(25 \pm 2^{\circ} \mathrm{C}\right)$ and illumination (12h-light/dark). Animals were allowed free access to normal rat chow diet and water ad libitum. This protocol was approved by the Animal Care and Use Committee of the Biochemistry Department, Faculty of Pharmacy, Zagazig University.

\section{Experimental work design}

One week after acclimatization, rats were randomly divided into two groups: normal controls, $n=10$ and $\mathrm{N}^{\mathrm{G}}$-nitro-L-arginine methyl ester (L-NAME), $n=40$. L-NAME was given in the drinking water $(0.1 \mathrm{mg} / \mathrm{ml})$ as inhibitor to nitric oxide synthesis which leads to systemic hypertension for two weeks before induction of diabetes.

Diabetes was induced by a single i.p. injection of streptozotocin, STZ, at a dose of 65 $\mathrm{mg} / \mathrm{kg}$ prepared in $0.1 \mathrm{M}$ citrate buffer, $\mathrm{pH} 4.2$, as described previously [18]. Seven days after STZ injection, blood glucose (BG) was measured enzymatically by a glucose oxidase method using Spinreact Diagnostics Kits (Spain), and animals were considered to be diabetic when the concentration of BG was equal to or higher than $200 \mathrm{mg} / \mathrm{dl}$. Diabetic hypertensive rats were subdivided into two groups: the first one was treated with cilostazol ( $n=12,1.8 \mathrm{mg}$ daily, orally) for 6 weeks [19] while the other group was left as a control $(n=15)$. Cilostazol was kindly provided by Otsuka Pharmaceutical Co. (Egypt) and other chemicals were purchased from Sigma Chemical, St. Louis, USA. At the end of the study, rats from each group were anaesthetized with urethane $(1.3 \mathrm{mg} / \mathrm{kg})$. Blood samples were collected for plasma and serum separation and then stored at $-80{ }^{\circ} \mathrm{C}$ as aliquots for further analysis.

\section{The method of recording of the arterial blood pressure and electrocardiogram (ECG)}

Animals were anaesthetized with ethyl carbamate (urethane) at a dose of $1.75-2.0 \mathrm{gm} / \mathrm{kg}$ i.p. as freshly prepared aqueous solution. The blood pressure and ECG were determined employing the reported method [20] through introduction of polyethylene arterial cannula with 3-way valve (filled with heparinized saline solution $16 \mathrm{I} . \mathrm{U} . / \mathrm{ml}$ to inhibit blood clotting) in the common carotid artery. The cannula was connected to PT 400 blood pressure transducer, which was connected to FC137 strain gauge coupler which was fixed to one of the 4-channel oscillograph $\mathrm{MD}_{4}$ (Bioscience, U.K.). The blood pressure was recorded on chart paper. The ECG limb cable was connected to FC123 coupler which switched on lead II and connected to another channel of the 4-channel oscillograph $\mathrm{MD}_{4}$.

$$
\text { Mean arterial pressure }=\text { Diastolic BP+1/3 (Systolic BP-Diastolic BP) }
$$




\section{Induction of venous thrombosis}

At the end of treatment period and twelve hours before induction of venous thrombosis, four rats from each group were deprived of food but had free access to water. The venous thrombosis was induced as previously described [21].The abdomen was opened under thiobarbital anesthesia (40 mg/ kg body weight i.p.); the vena cava was carefully separated from the surrounding tissues and then ligated tightly with a cotton thread just below the left renal vein. Subsequently, the abdomen was closed with a double layer of sutures (peritoneum with muscles and skin separately). After $4 \mathrm{~h}$ the animals were anesthetized again and the abdomen was then re-opened, the vena cava was carefully dissected and inspected for the presence of a thrombus. The thrombus was air-dried at $37^{\circ} \mathrm{C}$ and after $24 \mathrm{~h}$, its weight was determined.

\section{Measurement of serum cyclic AMP and plasma nitric oxide content}

The Adenosine 3',5'-cyclic monophosphate (cAMP) levels were evaluated by a Parameter ${ }^{\mathrm{TM}}$ ELISA kit (R\&D Systems) according to the kit's instructions. Plasma nitric oxide (NO) was measured as nitrite concentration after the reduction of nitrate to nitrite using Griess reagent. The nitrite concentration was measured at $546 \mathrm{~nm}$ using standard sodium nitrite [22].

\section{Transforming growth factor- $\beta_{1}$ and plasminogen activator inhibitor-1 Assay}

Serum TGF- $\beta_{1}$ [23] and plasma PAI-1 [24] were evaluated by ELISA technique using kits purchased from Biosource (USA) and Hyphen Bio Med (France), respectively.

The samples were acidified using $4 \mathrm{mM} \mathrm{HCl}$ to activate a latent form of TGF- $\beta_{1}$, making it accessible for measurement in the immunoassay.

\section{Determination of serum lipogram pattern}

Serum total cholesterol (TC), triacylglycerols (TAG), high density lipoprotein cholesterol (HDL-C) and low density lipoprotein cholesterol (LDL-C) were estimated enzymatically [25], using Spinreact diagnostics kits (Spain).

\section{Statistical analyses}

Results were expressed as means \pm S.D. Comparisons between groups were conducted by one-way ANOVA followed by the multiple comparison tests (least significant different, LSD) (SPSS program, Chicago, IL). The statistical associations between functional parameters were assayed using Spearman's nonparametric correlation analysis. $P<0.05$ was the established level of significance.

\section{Results}

\section{Effect of cilostazol treatment on hyperglycemia}

STZ-induced diabetes in Wistar rats recapitulates many aspects of type 1 diabetes in humans and is the most commonly used animal model for the study of diabetes-induced complications $[18,26]$. Hyperglycemia was detected in diabetic hypertensive animals and was not altered in cilostazol- treated groups compared to nontreated animals (Table 1). 
Tab. 1. Values of various parameters in normal rats, cilostazol-treated and -untreated diabetic hypertensive rats

\begin{tabular}{|c|c|c|c|c|}
\hline Parameters & $\begin{array}{l}\text { Control } \\
\text { Normal } \\
\text { rats } \\
\end{array}$ & $\begin{array}{l}\text { Control } \\
\text { Diabetic } \\
\text { hypertensive rats }\end{array}$ & $\begin{array}{l}\text { Cilostazol } \\
\text { treatment }\end{array}$ & $\mathbf{p}$ \\
\hline S-Glu (mg/c & & & & \\
\hline & 3.2 & $5.9^{*}$ & & \\
\hline $\mathrm{DBP}(\mathrm{mmHg})$ & $90 \pm 2.1$ & $120 \pm 3.4^{*}$ & & 001 \\
\hline MAP & $100.0 \pm 1.28$ & $136.7 \pm 2.1$ & $2.9^{* \#}$ & \\
\hline HR(beat/min) & $240 \pm 15$ & $320 \pm 13^{*}$ & & 0.008 \\
\hline \multicolumn{5}{|c|}{$\begin{array}{l}\text { Key: S-Glu=serum glucose concentration; } S B P=\text { systolic blood pressure; } \\
\text { DBP= diastolic blood pressure; MAP= mean arterial pressure; HR= heart } \\
\text { rate. Values were expressed as means } \pm S D .,{ }^{*} P<0.001 \text { v.s normal rats, }{ }^{\#} P \\
\text { v.s diabetic hypertensive control. NS, non significant difference from } \\
\text { diabetic hypertensive control. }\end{array}$} \\
\hline
\end{tabular}

\section{Effect of cilostazol on blood pressure and heart rate}

As shown in Table1, the systolic, diastolic blood pressure, mean arterial pressure, and heart rate were significantly higher in diabetic hypertensive rats as compared with normal rats $(\mathrm{P}<0.001)$. Treatment with cilostazol significantly decreased these parameters $(21.42 \%),(20.0 \%),(20.65 \%)$ and $(14.8 \%)$, respectively in our established diabetic hypertensive rats.

\section{Effect of cilostazol on serum cyclic AMP and plasma nitric oxide content}
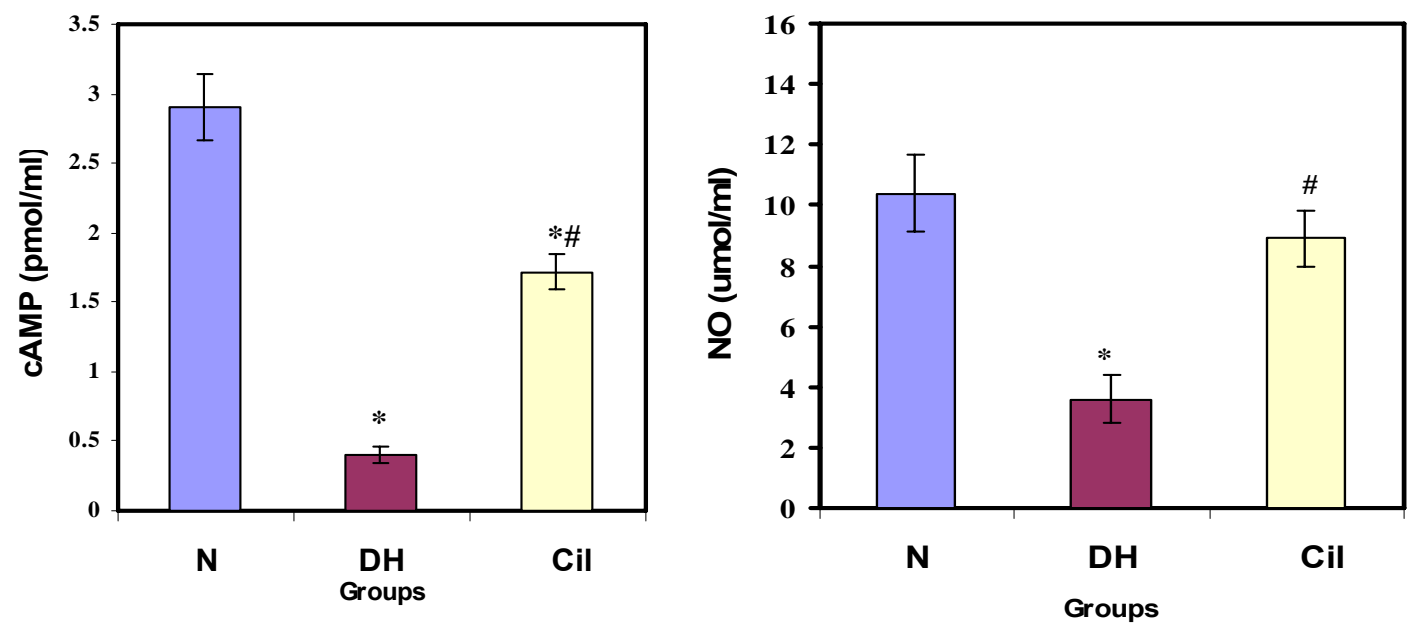

Fig. 1. Effect of cilostazol treatment on serum cAMP $(\mathrm{pmol} / \mathrm{ml})$ and plasma $\mathrm{NO}(\mu \mathrm{mol} / \mathrm{ml})$ in diabetic hypertensive rats. All values were expressed as means \pm S.D., ${ }^{*} P$ $<0.001$ vs. normal rats, ${ }^{\#} \mathrm{P}<0.001$ vs. diabetic hypertensive control. $\mathrm{N}$ (normal rats), $\mathrm{DH}$ (diabetic hypertensive rats), Cil (cilostazol treatment). 
The effect of L-NAME and STZ combination on serum cyclic AMP and plasma NO levels were summarized in Fig. (1), which showed significant decrease in both cyclic AMP (from $2.9 \pm 0.24$ to $0.4 \pm 0.06$ ) and plasma NO levels (from $10.4 \pm 1.3$ to $3.6 \pm 0.8$ ) as compared to normal group. Treatment with cilostazol for 6 weeks led to significant increase in serum cyclic AMP from $0.4 \pm 0.06$ to $1.72 \pm 0.13(P<0.001)$ and plasma NO level from $3.6 \pm 0.8$ to $8.9 \pm 0.9(P<0.001)$.

\section{Effect of cilostazol treatment on PAl-1 activity and dry thrombus weight}

Figure (2) showed that plasma PAI-1 activity and dry thrombus weight were significantly increased in diabetic hypertensive rats at $P<0.001$. Treatment with cilostazol for 6 weeks significantly decreased both plasma PAl-1 activity from $3.6 \pm 0.5$ to $0.85 \pm 0.07 \quad(P<0.001)$ and venous thrombus weight from $2.7 \pm 0.21$ to $1.2 \pm 0.14(P<0.001)$.
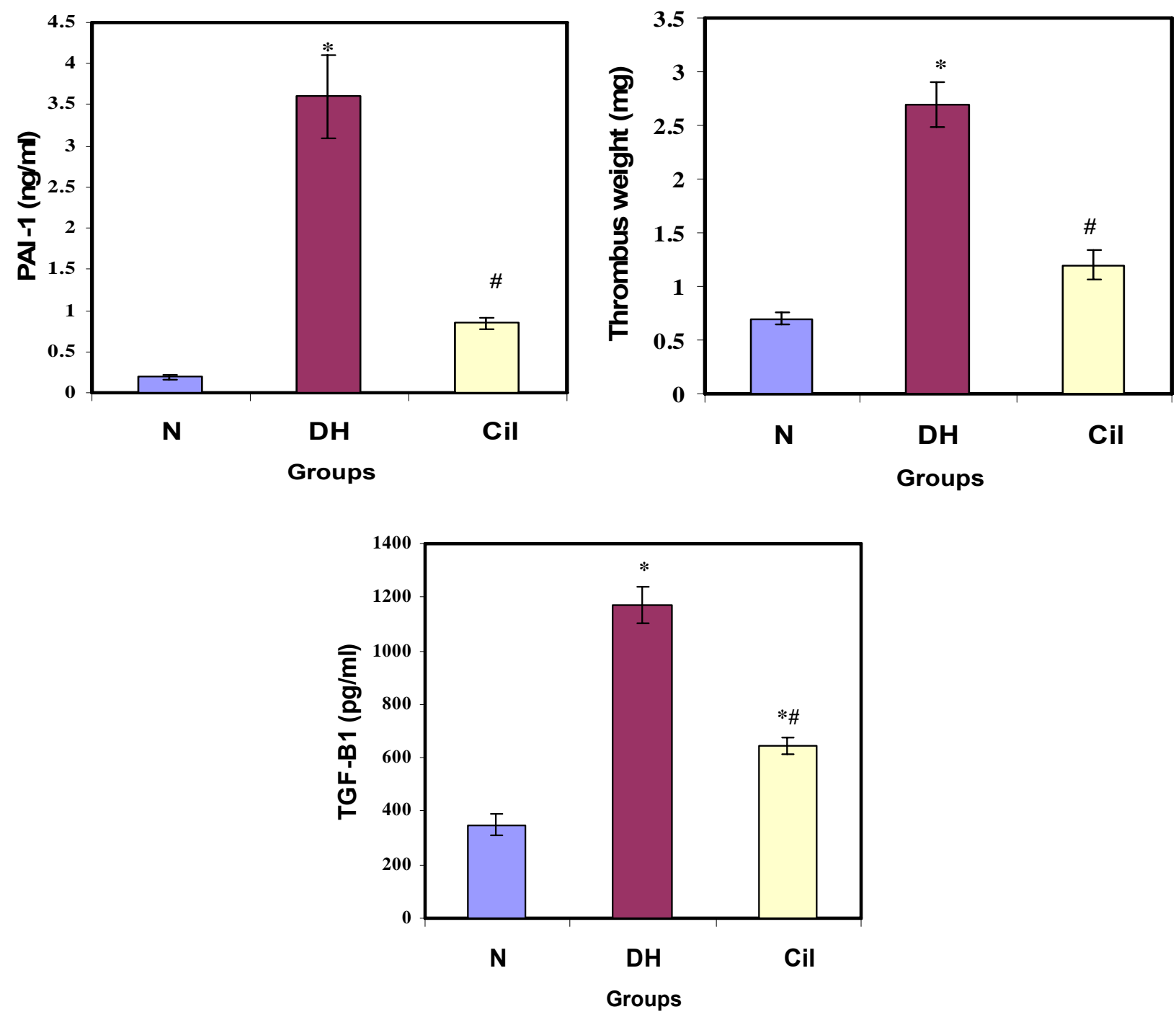

Fig. 2. Effect of cilostazol treatment on plasma PAl-1 ( $\mathrm{ng} / \mathrm{ml}$ ), dry thrombus weight (mg), and serum TGF $-\beta_{1}(\mathrm{pg} / \mathrm{ml})$ in diabetic hypertensive rats. All values were expressed as means \pm S.D., ${ }^{*} P<0.001$ vs. normal rats, ${ }^{\#} P<0.001$ vs. diabetic hypertensive control. 
$\mathrm{N}$ (normal rats), DH (diabetic hypertensive rats), Cil (cilostazol treatment).

\section{Effect of cilostazol treatment on TGF- $\beta_{1}$}

The transforming growth factor- $\beta_{1}$ is remarkably increased in diabetic hypertensive animals by $70.08 \%$ vs. normal rats. Cilostazol-treatment caused $81.11 \%$ significant reduction in this parameter as compared to nontreated group (Fig. 2).

\section{Effect of cilostazol treatment on serum lipoproteins}

Table 2 revealed that TC, TAG, LDLC and atherogenic indexes (TC/HDLC and LDLC/HDLC) were markedly increased while HDLC was significantly decreased at $P>0.001$ in diabetic hypertensive group as compared to normal rats. After 6 weeks of cilostazol treatment, there was a significant decrease in total cholesterol $(22.3 \%)$, serum triglycerides (35.46\%) and LDLC (30.5\%). Moreover, the two atherogenic indexes (TC/HDLC and LDLC/HDLC) were significantly decreased by $50.0 \%$ and $52.0 \%$, respectively. In addition, significant increase in HDL-C level was observed upon comparison the treated group with nontreated one (Table 2).

Tab. 2. Effect of cilostazol treatment on lipogram pattern in diabetic hypertensive rats.

\begin{tabular}{lllll}
\hline Parameters & $\begin{array}{l}\text { Control } \\
\text { Normal } \\
\text { rats }\end{array}$ & $\begin{array}{l}\text { Control } \\
\text { Diabetic } \\
\text { hypertensive } \\
\text { rats }\end{array}$ & $\begin{array}{l}\text { Cilostazol } \\
\text { treatment }\end{array}$ & $\mathbf{P}$ \\
\hline $\mathrm{TC}(\mathrm{mg} / \mathrm{dl})$ & $97 \pm 10$ & $170 \pm 13^{*}$ & $139 \pm 9.4^{\#}$ & 0.013 \\
$\mathrm{TAG}(\mathrm{mg} / \mathrm{dl})$ & $84 \pm 7$ & $123 \pm 7.4^{*}$ & $90.8 \pm 9^{\#}$ & 0.002 \\
$\mathrm{LDLC}(\mathrm{mg} / \mathrm{dl})$ & $50 \pm 9$ & $92 \pm 5^{*}$ & $70.5 \pm 6^{\#}$ & 0.009 \\
$\mathrm{HDLC}(\mathrm{mg} / \mathrm{dl})$ & $33 \pm 2.6$ & $24 \pm 1.1^{*}$ & $29 \pm 1.4^{\#}$ & 0.015 \\
$\mathrm{TC} / \mathrm{HDLC}$ & $2.9 \pm 0.32$ & $7.2 \pm 1.13^{*}$ & $4.8 \pm 0.23^{\#}$ & 0.005 \\
LDLC/HDLC & $1.52 \pm 0.25$ & $3.8 \pm 0.13^{*}$ & $2.5 \pm 0.31^{\#}$ & 0.001 \\
\hline
\end{tabular}

Key: $T C=$ total cholesterol; TAG = triaceylglycerol; $L D L C=$ low density lipoprotein cholesterol; HDLC= high density lipoprotein cholesterol. Values were expressed as means \pm SD., ${ }^{*} P<0.001$ v.s normal rats, ${ }^{\#} P$ v.s diabetic hypertensive control.

\section{Discussion}

The present study have shown that coexist of diabetes and hypertension in experimental animals has resulted in a decreased levels of NO and CAMP. In fact, the decreased level of such parameters may be attributable to endothelial dysfunction which, in turn led to cardiovascular disorders.

The previous study reported that powerful inhibition of NO biosynthesis causes severe cardiovascular disorders in rats treated with high dose of L-NAME [27]. These disorders are due to decrease in production or bioavailability of nitric oxide that associated with a decrease in cyclic GMP and cyclic AMP content [28] leading to hypertension and consequently accelerate the progression of CVC [29]. 
In addition, other reports documented that endothelial dysfunction represents a common patho-physiological pathway of diabetic complications which play a central role in cardiovascular complications [30]. It was also observed that endothelial dysfunction led to vascular dysfunction as evidenced by reduced endothelial nitric oxide-mediated vasorelaxation which causes increase in arterial pressure [31].

$\mathrm{PAl}-1$ is plasmatic marker that reflects endothelial cell damage and its elevated level in cardiovascular disorders confirmed this phenomenon [32]. Moreover, PAl-1 is a prominent causative factor in several progressive and chronic fibrotic disorders, particularly in the context of elevated tissue TGF- $\beta_{1}$ levels, as well as an important contributor to the pathophysiology of vascular sclerosis [33]. TGF- $\beta$ is a key player in the fibrotic response, whereas it activates TGF- $\beta$ receptors causing activation of Smad proteins especially Smad3/4 which acts as transcription factors [34, 35]. This activation led to enhancement of transcription of numerous genes, including connective tissue growth factor, plasminogen activator inhibitor-1 and various collagen genes [36].

The results presented in this study clearly showed the presence of higher levels of PAI-1 and TGF- $\beta_{1}$ in diabetic hypertensive rats when compared with normal rats. Moreover, a direct correlation between PAI-1 and TGF- $\beta_{1}(r=0.92, P<0.001)$ was also observed. Thus, blocking TGF- $\beta_{1}$ signal transduction should reduce PAI-1 production, blunt fibrosis, maintain normal endothelium function, and finally suppress progression of cardiovascular complications.

Our findings revealed that administration of cilostazol for 6 weeks improved endothelial functions, in part, through an increasing in serum cAMP and plasma NO levels, besides it decreased the arterial blood pressure in diabetic hypertensive animals due to its vasodilatation effect.

Several reports documented our results whereas one study demonstrated that cilostazol caused an increase in serum cAMP presumably by reducing its hydrolysis due to inhibition of phosphodiesterase type III [37]. In addition, others illustrated that cilostazol stimulates NO production via the activation of cAMP-dependent protein kinase (protein kinase A; PKA) [38] owing to inducing phosphorylation of eNOS at Ser-1177 [39].

Furthermore, another study explained the role of cilostazol in increasing cyclic AMP via an increase in the nitric oxide production which causes activation of soluble guanylate cyclase leading to an increase in the cGMP level. The increased level of cyclic GMP could inactivate PDE3, thereby increasing the cAMP concentration which causing further dilatation, increasing peripheral blood flow and inhibiting the proliferation of vascular smooth muscle cells [40].

This work demonstrated that supplementary daily doses of cilostazol $1.8 \mathrm{mg}$ induced a significant reduction of plasma PAI-1, serum TGF- $\beta_{1}$, and also inhibiting the venous thrombus formation due to its well known antithrombotic effect. Moreover, there is a strong negative correlation between PAI- 1 and cAMP ( $r=0.90, P<0.001)$ as well as TGF- $\beta_{1}$ and cAMP ( $r=0.98, P<0.0001)$. Thus, cilostazol can protect diabetic hypertensive animals from the progression of cardiovascular disorders through several ways: firstly, by improvement of endothelial dysfunction; secondly, by its direct action in reducing overexpression of TGF- $\beta_{1}$ which, in turn inhibits PAI-1 production via interaction with the TGF- $\beta$ signaling 
pathway; thirdly, by inhibiting the venous thrombus formation; and finally through modifying lipoproteins.

Previous study presented definitive evidence that cAMP-elevating agents block Smad3/4specific transcription in response to TGF- $\beta$, as well as PAI-1 gene expression at the transcriptional level [41]. Another work suggested that activation of the cAMP/PKA signaling pathway inhibits Smad-mediated transcription by abolishing Smad interaction with key transcriptional activators [42].

Moreover, cilostazol also favorably modifies lipoproteins through elevation of cAMP [43]. There are several possible mechanisms by which the increased cAMP might led to decreasing in serum triglycerides. One possible mechanism is via reducing hepatic triglyceride (ie, VLDL) secretion [44] and the other one depends on promoting the release of lipoprotein lipase from rat adipocytes [45] which could reduce serum triglycerides.

\section{Conclusions}

It can be concluded that the findings of current study indicate that the drug interfering with the cAMP pathway offer therapeutic opportunity to alleviate cardiovascular complications. The phosphodiesterase type III inhibitor cilostazol fulfills this idea whereas it improves cAMP level leading to increase in NO concentration causing a decrease in arterial blood pressure. Moreover, it decreases overexpression of TGF- $\beta_{1}$ and also prevents thrombosis via inhibition of plasma PAI-1 activity. Consequently, cilostazol therapy provides a broad spectrum of effects in alleviating cardiovascular complications induced in experimental animals.

\section{Acknowledgement}

The author would like to thank Dr. Ibrahim A. Awwad, Faculty of Medicine, Zagazig University, Zagazig, Egypt, for his assistance in the pharmacological study.

\section{Author's Statements}

\section{Competing Interests}

The author declares no conflict of interest.

\section{Animal Rights}

The institutional and (inter)national guide for the care and use of laboratory animals was followed. See the material and methods part for details.

\section{References}

[1] Schäfer A, Bauersachs J.

Endothelial dysfunction, impaired endogenous platelet inhibition and platelet activation in diabetes and atherosclerosis.

Curr Vasc Pharmacol. 2008; 6: 52-60.

doi:10.2174/157016108783331295 
[2] Grossman E, Messerli FH.

Diabetic and hypertensive heart disease.

Ann Intern Med. 1996; 125: 304-310.

PMid:8678395

[3] Sampaio RC, Tanus-Santos JE, Melo SE, Hyslop S, Franchini KG, Luca IM, Moreno H.

Hypertension plus diabetes mimics the cardiomyopathy induced by nitric oxide inhibition in rats.

Chest. 2002; 122: 1412-1420.

doi:10.1378/chest.122.4.1412

[4] Sowers JR, Epstein M, Frohlich ED.

Diabetes, hypertension, and cardio-vascular disease: an update.

Hypertension. 2001; 37, 1053-1059.

PMid:11304502

[5] Fuster V, Badimon L, Badimon JJ, Chesebro JH.

The pathogenesis of coronary artery disease and the acute coronary syndromes.

N Engl J Med. 1992; 326: 242-250.

PMid:1727977

[6] Cines DB, Pollak E, Buck CA, Loscalzo J, Zimmerman GA, McEver RP, Pober JS, Wick TM, Konkle BA, Schwartz BS, Barnathan ES, McCrae KR, Hug BA, Schmidt AM, Stern DM.

Endothelial cell in physiology and in the pathophysiology of vascular disorders.

Blood. 1998; 91: 3527-3561.

PMid:9572988

[7] Petzelbauer E, Springhorn JP, Tucher AM, Madri JA.

Role of plasminogen activator inhibitor in the reciprocal regulation of bovine aortic endothelial and smooth muscle cell migration by TGF- $\beta_{1}$.

Am J Pathol. 1996; 149: 923-931.

PMid:8780396

[8] Rerolle JP, Hertig A, Nguyen G, Sraer JD, Rondeau EP. Plasminogen activator inhibitor type 1 is a potential target in renal fibrogenesis.

Kidney Int. 2000; 58: 1841-1850.

doi:10.1111/j.1523-1755.2000.00355.x

[9] Shigeki O, Masakazu T, Masashi D, Toshinaga T, Yoshinari G, Kiyoshi N.

Novel transcriptional factor with Ser/Thr kinase activity involved in the trans-forming growth factor

(TGF)- $\beta$ signalling pathway.

Biochem J. 2000; 350: 395-404.

doi:10.1042/0264-6021:3500395

[10] Schulz E, Jansen T, Wenzel P, Daiber A, Münzel T.

Nitric oxide, tetra-hydrobiopterin, oxidative stress, and endothelial dysfunction in hypertension.

Antioxid Redox Signal. 2008; 10:1115-1126.

doi:10.1089/ars.2007.1989

[11] Fadillioglu E, Erdogan $\mathrm{H}$, Polat $\mathrm{A}$, Emre $\mathrm{MH}$.

Renal antioxidant status in rats with hypertension induced by $\mathrm{N}$ sup omega nitro-L-arginine methyl ester.

Kidney Blood Press Res. 2002; 25: 211-216.

doi:10.1159/000066341

[12] Horn NA, Anastase MD, Hecker EK, Baumert HJ, Scheffer JG, Rossaint R.

Phosphodiesterase III inhibition affects platelet monocyte aggregate formation depending on the axis of stimulation.

J Cardiothor Anesth. 2006; 20: 162-166.

doi:10.1053/j.jvca.2005.11.007 
[13] Dousa TP.

Cyclic-3',5'-nucleotide phosphodiesteraseisozymes in cell biology and pathophysiology of the kidney.

Kidney Int. 1999; 55: 29-62.

doi:10.1046/j.1523-1755.1999.00233.x

[14] Sudo T, Tachibana K, Toga K, Tochhizawa S, Inoue Y, Kimura Y, Hidaka H.

Potent effects of novel anti-platelet aggregatory cilostamide analogues on recombinant cyclic

nucleotide phosphodiesterase isozyme activity.

Biochem Pharmacol. 2000; 59: 347-356.

doi:10.1016/S0006-2952(99)00346-9

[15] Kambayashi J, Liu Y, Sun B, Shakur Y, Yoshitake M, Czerwiec F.

Cilostazol as a unique antithrombotic agent.

Curr Pharm Des. 2003; 9: 2289-2302.

doi:10.2174/1381612033453910

[16] Kimura Y, Tani T, Kanbe T, Watanabe K.

Effect of cilostazol on platelet aggregation and experimental thrombosis.

Arzneimittelforschung. 1985; 35:1144-1149.

PMid:4074426

[17] Ikewaki K, Mochizuki K, Iwasaki M, Nishide R, Mochizuki S, Tada N.

Cilostazol, a potent phosphodiesterase type III inhibitor, selectively increases anti-atherogenic highdensity lipoprotein subclass LPA-I and improves post-prandial lipemia in patients with type 2 diabetes mellitus.

Metabolism. 2002; 5: 1348-1354.

doi:10.1053/meta.2002.35191

[18] Bagrov YY, Manusova NB, Egorova IA, Fedorova OV, Bagrov AY.

Endogenous digitalis-like ligands and $\mathrm{Na} / \mathrm{K}-\mathrm{ATPase}$ inhibition in experimental diabetes mellitus.

Front Biosci. 2005;10: 2257-2262.

doi:10.2741/1695

[19] Matsumoto T, Kobayashi T, Wakabayashi K, Kamata K.

Cilostazol improves endothelium-derived hyperpolarizing factor-type relaxation in mesenteric arteries from diabetic rats.

Am J Physiol Heart Circ Physiol. 2005; 289: H1933-H1940.

doi:10.1152/ajpheart.00303.2005

[20] Burden DT, Blaber LC, Natoff IL.

A simple method for recording left ventricular pressure and heart rate in the conscious cat.

Pharmacol Ther. 1979;5: 99-102.

doi:10.1016/0163-7258(79)90076-7

[21] Reyers I, Gaetano G, Donati M.

Venostasis induced thrombosis in rats is not influenced by circulating platelet or leukocyte number.

Agents Actions. 1989; 28: 137-141.

doi:10.1007/BF02022994

[22] Moshage H, Kok B, Huizenga JR, Jansen PL.

Nitrite and nitrate determinations in plasma: a critical evaluation.

Clin Chem. 1995; 41: 892-896.

PMid:7768008

[23] Kim S, Romeo D, Yoo Y, Park K.

Transforming growth factor-beta: Expression in normal and pathological condition.

Horm Res. 1994; 42: 5-8.

PMid:7959634

[24] Ngo T, Bijnens A, Knockaet I, Declerck P.

Expression, purification, and characterization of recombinant rat plasminogen activity inhibitor-1.

Fibrinol Proteol. 1997; 11: 37-43.

doi:10.1016/S0268-9499(97)80007-0 
[25] The recognition and management of hyperlipidaemia in adults: A policy statement of the European Atherosclerosis Society.

Euro Heart J. 1988; 9: 571-600.

PMid:3402474

[26] Brondum E, Nilsson H, Aalkjaer C.

Functional abnormalities in isolated arteries from Goto-Kakizaki and streptozotocin-treated diabetic rat models.

Horm Metab Res. 2005; 37: 56-60.

doi:10.1055/s-2005-861370

[27] Darblade B, Batkai S, Caussé E, Gourdy P, Fouque MJ, Rami J, Arnal JF.

Failure of L-nitroarginine to inhibit the activity of aortic inducible nitric oxide synthase.

J Vasc Res. 2001; 38: 266-275.

doi:10.1159/000051055

[28] Matsumoto T, Wakabayashi K, Kobayashi T, Kamata K. Diabetes- related changes in cAMPdependent protein kinase activity and decrease in relaxation response in rat mesenteric artery. Am J Physiol Heart Circ Physiol. 2004; 287: H1064-H1071.

doi:10.1152/ajpheart.00069.2004

[29] Yang R, Powell-Braxton L, Ogaoawara AK, Dybdal N, Bunting S, Ohneda O, Jin H. Hypertension and endothelial dysfunction in apolipo-protein $E$ knockout mice.

Arterioscler Thromb Vasc Biol. 1999; 19: 2762-2768.

PMid:10559023

[30] Laight D, Carrier M, Anggard E.

Antioxidants, diabetes and endothelial dysfunction.

Cardiovasc Res. 2000; 47: 457-464.

doi:10.1016/S0008-6363(00)00054-7

[31] Feldt-Rasmussen $B$.

Microalbuminuria, endothelial dysfunction and cardio-vascular risk.

Diabetes Metab. 2000; 26: 64-66.

PMid:10922975

[32] Juhan-Vague I, Alessi MC.

PAI-1, obesity, insulin resistance and risk of cardiovascular events.

Thromb Haemost. 1997; 78: 656-660.

PMid:9198234

[33] Vaughan DE.

PAI-1 and TGF- $\beta$ : unmasking the real driver of TGF- $\beta$-induced vascular pathology.

Arterioscler Thromb Vasc Biol. 2006; 26: 679-680.

doi:10.1161/01.ATV.0000209949.86606.c2

[34] Feng XH Derynck R.

Specificity and versatility in TGF- signaling through Smads.

Annu Rev Cell Dev Bio. 2005; 21: 659-693.

doi:10.1146/annurev.cellbio.21.022404.142018

[35] Chen S, Kulik M, Lechleider RJ.

Smad proteins regulate transcriptional induction of the SM22alpha gene by TGF-beta.

Nucleic Acids Res. 2003; 31: 1302-1310.

doi:10.1093/nar/gkg224

[36] Leask A, Holmes A, Black CM, Abraham DJ.

Connective tissue growth factor gene regulation: Requirements for its induction by transforming growth factor- $\beta 2$ in fibroblasts.

J Biol Chem. 2003; 278: 13008-13015.

doi:10.1074/jbc.M210366200 
[37] Lee JH, Oh GT, Park SY, Choi JH, Park JG, Kim CD, Lee WS, Rhim BY, Shin YW, Hong KW. Cilostazol reduces atherosclerosis by inhibition of super-oxide and TNF- $\alpha$ formation in low-density lipoprotein receptor-null mice fed high cholesterol.

J Pharmacol Exp Ther. 2005; 313: 502-509.

doi:10.1124/jpet.104.079780

[38] Montminy M.

Transcriptional regulation by cyclic AMP.

Annu Rev Biochem. 1997; 66: 807-822.

doi:10.1146/annurev.biochem.66.1.807

[39] Manickavasagam S, Ye Y, Lin Y, Perez-Polo RJ, Huang MH, Lui CY, Hughes MG, McAdoo DJ, Uretsky BF, Birnbaum Y.

The cardio-protective effect of a statin and cilostazol combination: relationship to Akt and endothelial nitric oxide synthase.

Cardiovasc Drugs Ther. 2007; 21: 321-330.

doi:10.1007/s10557-007-6036-0

[40] Mitsuhasi N, Tanaka Y, Kubo S, Ogawa S, Hayashi C, Uchino H, Shimizu T, Watada H, Kawasumi M,Onuma T, Kawamori R.

Effect of cilostazol, phosphordiesterase inhibitor, on carotid IMT in Japanese type 2 diabetic patients. Endocr J. 2004; 51: 545-550.

doi:10.1507/endocrj.51.545

[41] Liu X, Sun S, Ostrom R.

Fibrotic lung fbroblasts show blunted inhibition by cAMP due to deficient cAMP response elementbinding protein phosphoryla-tion.

J Pharmacol Exp Ther. 2005; 315: 678-687.

doi:10.1124/jpet.105.090324

[42] Schiller M, Verrecchia F, Mauviel A.

Cyclic adenosine 3',5'-mono-phosphate-elevating agents inhibit transforming growth factor-betainduced SMAD3/4-dependent transcription via a protein kinase A-dependent mechanism.

Oncogene. 2003; 22: 8881-8890.

doi:10.1038/sj.onc.1206871

[43] Manganiello VC, Taira M, Degerman E, Belfrage P.

Type III cGMP inhibited cyclic nucleotide phosphodiesterases (PDE3 gene family).

Cell Signal. 1995; 7: 445-455.

doi:10.1016/0898-6568(95)00017-J

[44] Bjornsson OG, Sparks JD, Sparks CE, Gibbons GF. Regulation of VLDL secretion in primary culture of rat hepatocytes: involvement of cAMP and CAMP-dependent protein kinases.

Eur J Clin Invest. 1994; 24: 137-148.

doi:10.1111/j.1365-2362.1994.tb00979.x

[45] Motoyashiki T, Morita T, Ueki H.

Involvement of the rapid increase in cAMP content in the vanadate-stimulated release of lipoproteins lipase activity from rat fat pads.

Biol Pharm Bull. 1996; 19: 1412-1416.

PMid:8951155 